\title{
Comunicação como ruptura: nuances de uma nova teoria brasileira
}

\section{Vanessa Matos dos Santos}

Doutora; Universidade Federal de Uberlândia, Uberlândia, MG, Brasil

vanessamatos@ufu.br

\section{Resumo}

A concepção de territórios discursivos engendra lugares políticos e, ainda que de uma forma indireta, pressupõe uma espécie de colonização cognitiva e epistêmica. Os estudos em Comunicação no Brasil e na América Latina ainda são maciçamente marcados por contribuições teóricas e conceitos que foram forjados levando em consideração contextos outros que não os da IberoAmérica. Objetivando apresentar um importante progresso alcançado no Brasil, este artigo apresenta a Nova Teoria da Comunicação (NTC) e o conceito de comunicação como ruptura e consequente abertura ao Outro. Dada esta abertura, a NTC não trabalha com a rigidez metodológica e sim com o rigor em narrar os acontecimentos através do metáporo. Busca-se demonstrar, sobretudo, que pesquisar com os procedimentos metapóricos enseja uma nova relação entre pesquisador e objeto de pesquisa, que permite vislumbrar novos olhares num campo tão complexo como o da Comunicação.

\section{Palavras-chave}

Nova Teoria da Comunicação. Ruptura. Epistemologia. Metáporo.

\section{Introdução}

A História da Ciência atesta que, após anos de obscurantismo, a humanidade experimentou, ainda que com rupturas, o gosto das inovações e nunca mais retrocederia ao que fora um dia (ROSA, 2012; BACHELARD, 2006). Esse movimento de transformação foi verificado nos mais diversos campos do Saber. 0 paradigma cartesiano-newtoniano exerceu domínio no que se refere à forma como os homens enxergavam o mundo até o final do século XIX, quando suas bases foram abaladas em virtude de novas descobertas científicas que ditaram a ruptura entre o mundo moderno e o contemporâneo. Um novo pressuposto 
sobre a Ciência ditava regras baseadas em experimentos, cálculos que deveriam ser constantemente checados e dados que, reproduzidos em laboratório, deveriam oferecer sempre o mesmo resultado como forma de atestar a cientificidade do que se propunha.

A vertente comunicacional (embora ainda seja bastante jovem se comparada à outras áreas do Saber como a Sociologia, a Matemática ou a Física, por exemplo) também sentiu esta turbulência científica. Caracterizada essencialmente pela contribuição oriunda de diversas áreas, a Comunicação foi concebida, inicialmente, como área interdisciplinar no que se refere ao estudo das teorias. Sobre este aspecto, é importante destacar, apenas a título de exemplo, a teoria matemática da comunicação (também chamada de Teoria da Informação), as influências do interacionismo simbólico de Mead etc. A concepção de que tudo deveria ser medido e calculado levou a um ofuscamento do sujeito nos processos comunicacionais. Prova disso é o fato de que durante muito tempo, nos estudos da área de Comunicação, principalmente nos relacionados às Teorias da Comunicação, as teorias administrativas ${ }^{1}$ receberam frequentemente diversas críticas por defenderem a ideia de um receptor passivo, cristalizado, incapaz de emitir uma resposta diante do poder avassalador exercido pelos meios de comunicação de massa.

Posteriormente, assistiu-se, ainda no campo comunicacional, a emergência da perspectiva qualitativa. Este foi, sem dúvida, um avanço para as pesquisas na área. Entretanto, ainda assim, a perspectiva qualitativa trabalhava (e ainda trabalha) essencialmente com aquilo que o sujeito verbaliza, demonstra etc. (tal como acontece nas pesquisas envolvendo a análise discursiva, por exemplo). Ignora-se que por muitos anos a sociedade vivencia o império da linguagem verbal em detrimento de outras possibilidades. Ignorar essas outras possibilidades (não verbais), ou ainda considerá-las inferiores, é também uma forma de silenciar o Outro, transformando-o, em última instância, em algo que ele efetivamente não é: receptor passivo.

No escopo das teorias comunicacionais, o Brasil se destacou por diversas contribuições que ajudaram a pensar a comunicação como ciência. Paulo Freire (1983), por exemplo, abriu o caminho na concepção de uma comunicação que fosse mais que mero processo e se transformasse em diálogo. Este material apresenta mais uma importante contribuição para pensar a comunicação como ciência. Trata-se da Nova Teoria da Comunicação (NTC). Para tanto, apresenta-se, inicialmente, um cenário das transformações

\footnotetext{
1 Teorias administrativas foram aquelas desenvolvidas no contexto dos Mass Communication Research. Marcondes Filho (2011) as classifica dessa forma porque eram pesquisas voltadas para o interesse de seus patrocinadores.
} 
que possibilitaram o surgimento desta nova forma de olhar a comunicação. Em seguida, apresentam-se seus pressupostos, alicerce, estatuto epistemológico e forma de investigação.

\section{Antecedentes: o mundo em transformação}

No campo da Biologia, Darwin introduziu uma nova forma de compreender o mundo vivente. Em sua obra A origem das espécies, de 1859, Darwin defendeu que o meio ambiente era capaz de exercer pressões sobre as espécies, forçando-as à adaptação e, consequentemente, selecionando os mais fortes e adaptáveis. Deste modo, pela primeira vez a ideia de que o homem domina a natureza começa a ser questionada. No campo da Física, a descoberta da Termodinâmica inaugurou uma nova área de estudo. A teoria quântica inaugurada por Max Planck demonstrou, na prática, que o mundo era mais complexo do que Descartes e Newton haviam imaginado. Considerado o pai da física quântica, Planck introduziu o conceito de átomos de energia, demonstrando que toda matéria é composta por partículas atômicas e subatômicas. Albert Einstein também ofereceu um novo horizonte para os estudos da natureza ao apresentar sua Teoria da Relatividade, que revelou que a condição espaço-temporal é relativa. 0 tempo, para ele, era muito diferente daquilo que nós vivenciamos cotidianamente. 0 cotidiano, portanto, como queria a ciência moderna (que, até então, se ancorava no pressuposto experimental de Francis Bacon), não é algo fixo que pode ser facilmente controlado e experimentado diversas vezes em laboratório oferecendo sempre o mesmo resultado; ele depende de uma série de coordenadas e dimensões de análise. A partir de Einstein, Bachelard (1996) começou a falar de um novo espírito científico, posto que as antigas fronteiras epistemológicas que delimitavam a ciência como algo fixo e estático, estavam passando por revisão.

Soma-se a isto o Princípio da Incerteza, de Heisenberg, criado em 1927. De acordo com os estudos de Heisenberg, não seria possível prever simultaneamente a posição e a velocidade de uma partícula, visto que seu comportamento sofre alterações e essa mesma partícula pode apresentar-se também como onda. Esse aspecto dual faz com que nada mais possa ser visto com parâmetros de certeza e sim por meio de probabilidades. Esse princípio demonstra que, no nível subatômico, os objetos não são sólidos, uma vez que são constituídos por partículas que podem se comportar como ondas e, como tal, descreverem movimentos ondulatórios. Nesse sentido, “[...] os materiais sólidos apresentam padrões ondulatórios de probabilidade, traduzidos como probabilidades de conexão." (MORAES, 
2000, p. 61), ou seja, tudo depende do olhar e do padrão de conexão vigente. Em linhas gerais, o Princípio da Incerteza demonstra que o mundo não obedece a uma lógica determinística, fechada. Nesse sentido, a física quântica descortina um mundo que não pode ser definido com segurança se suas conexões não forem levadas em conta. Desta forma, a divisão não é mais feita em grupos de objetos, mas sim em função das conexões que esses objetos estabelecem em um determinado contexto. Mais recentemente, o físico-químico Ilya Prigogine apresentou a teoria das estruturas dissipativas, que toma por base a ideia de sistemas abertos. Ao contrário da física clássica, que se alicerçava em sistemas deterministas e fechados, Prigogine entende que o universo é formado por sistemas abertos. Para ele, as leis fundamentais da física devem conduzir a uma base evolutiva, mas, para que isso seja possível, é preciso incorporar elementos como o indeterminismo, a assimetria do tempo e a irreversibilidade. Para Prigogine, o primeiro elemento diz respeito não à ausência da previsibilidade, mas sim aos seus limites. Além disso, é preciso levar em consideração a existência de uma "[...] quebra de simetria temporal, ou seja, a direção do tempo é comum ao aparelho de medida e ao observador." (MASSONI, 2008, p. 7).

A irreversibilidade, por sua vez, pode ser expressa pelo fato de que as transformações são irreversíveis e sempre conduzem a novos estados. Prigogine desenvolve a ideia de estruturas que estão em desequilíbrio e que, portanto, apresentam instabilidade. Sobre esse aspecto, Massoni (2008, p. 3) explica que a ausência de equilíbrio é capaz de tornar possível o aparecimento do complexo e, de acordo com ela, “[...] as estruturas biológicas, a auto-organização; a vida só é possível longe do equilíbrio. Isso mostra que o caos assume um papel construtivo." Por essa razão, Prigogine busca a generalização do conceito de caos, visto que este não significa a desordem, mas sim a possibilidade de alcançar um novo estágio evolutivo. Nesse sentido, “[...] estruturas dissipativas são próprias de processos irreversíveis e revelam que ocorre a criação de ordem longe do equilíbrio termodinâmico." (MASSONI, 2008, p. 3) As estruturas dissipativas, constituintes da maior parte do Universo, são assim chamadas porque dissipam energia e têm seu funcionamento calcado em uma lógica aleatória. Não se trata, portanto, de um princípio mecânico. 0 princípio aleatório, por seu turno, é que permite saltos de criatividade, novidade e que conduz a um contexto mais pluralista. De uma forma geral, Prigogine introduziu a ideia de que um universo está em constante transformação e de que o caos, embora possa parecer paradoxal, pode conduzir a estados de ordem. Do ponto de vista da organização social, a teoria de Prigogine abre as possibilidades de inovação ilimitada, decorrente de que "[...] 
tanto as moléculas como as ondas cerebrais, os indivíduos e as sociedades possuem um potencial ilimitado de transformação cujos limites desconhecemos." (MORAES, 2000, p. 69).

A Ciência evoluiu e, aos poucos, o homem passou do paradigma cartesianonewtoniano para o paradigma quântico, mas, paradoxalmente, isso não significou uma melhora da qualidade de vida psíquica do ser. Ao contrário, diversos autores, a exemplo de Bauman e Chomsky, têm declarado a liquidez das relações humanas na contemporaneidade e os estragos que a estrutura das sociedades atuais tem ocasionado na humanidade. 0 pano de fundo dessas críticas talvez seja o "vazio" sentido pelo ser mesmo diante de tantas tarefas cotidianas. Agamben (2005, p. 22) afirma que "[...] o homem moderno volta para casa à noitinha extenuado por uma mixórdia de eventos - divertidos ou maçantes, banais ou insólitos, agradáveis ou atrozes -, entretanto nenhum deles se tornou experiência.". Na concepção do autor, é justamente essa incapacidade de se transformar em experiência que tem tornado o cotidiano das pessoas algo "insuportável" na contemporaneidade. Tal aspecto, no entanto, não quer dizer que a vida esteja sem importância ou carente de qualidades significativas. Na verdade, nunca o homem esteve tão cercado de situações significativas. O que ocorre é que, além da questão do entorpecimento dos sentidos ocasionado justamente pelo excesso de conteúdos (como veremos adiante), o correlato da experiência não é o conhecimento e sim a autoridade (expressa pela palavra e pelo conto). Neste cenário, a comunicação tem se transformado em mera troca de sinais e não como algo significativo, capaz de alterar a vida do ser humano. Trata-se de uma espécie de acúmulo, mas de vazios.

\section{Trilhando o percurso de uma nova visão sobre a Comunicação}

Neste cenário de acúmulo de vazios, a Nova Teoria da Comunicação (NTC) surge com a proposta de libertar o pesquisador e, ao mesmo tempo, de expor uma nova dimensão do que vem a ser comunicação. A concepção de que "tudo é comunicação", ou ainda de que "é impossível não se comunicar", levou a dois cenários importantes e que merecem destaque neste estudo porque ambos exercem grande influência no cotidiano. 0 primeiro apregoou a óptica de que não há especificidade alguma na comunicação, posto que "tudo" é comunicação. De acordo com essa lógica, se todos os seres se comunicam, não há nada de especial nisso e, por extensão, não se trataria sequer de uma área de estudos. Esse ponto de vista, embora superado por diversos estudos, ainda gera debates veementes. Prova maior 
disso é o fato de que, até hoje (2017), a obrigatoriedade do curso superior de Jornalismo ainda continua sendo questionada pela Justiça brasileira, que ainda insiste em desconsiderar a diferença existente entre liberdade de expressão e liberdade de imprensa. A segunda concepção, ou seja, a de que "é impossível não se comunicar", levou ao que Berger (2007) chama de "perambulações interdisciplinares". Em grande medida, isso se deve também à assunção de que tudo (e todos, por extensão) é comunicação. Não por acaso, as pesquisas conduzidas no contexto dos Mass Media Research foram também chamadas de pesquisas administrativas (MARCONDES FILHO, 2011). Ao longo do tempo, outras áreas também ofereceram suas contribuições e influências: a Linguística, a Sociologia, a Psicologia, a Matemática, a Engenharia. Para cada uma dessas áreas, a comunicação assume um conceito diferente e, como tal, também pressupõe um conjunto de técnicas que respaldam a pesquisa desenvolvida com tais conceitos (LITTLEJOHN, 1978; MARTINO, 2009; SODRÉ, 2014).

Se, por um lado, tal aspecto denota a importância e permeabilidade da comunicação, por outro, este parece ser também seu calcanhar de Aquiles na busca por maioridade científica. O lugar da Comunicação - como ciência, daí a inicial maiúscula - segue em constante debate em meio a um cenário cada vez mais fluido. Na tentativa de compreender esta nova ciência, Sodré (2014) entende que se trata de uma ciência que se respalda no comum humano (indo desde as questões subjetivas até as relações midiáticas). A busca do autor em estabelecer o estatuto epistemológico da Comunicação como ciência o faz admitir que o método comunicacional aponta para o problema do comum e se apoia veementemente na questão metodológica. 0 ponto de vista deste respeitado expoente dos estudos de Comunicação no Brasil se alinha à ideia comumente disseminada de que uma ciência exige, necessariamente, um método para que possa ser assim reconhecida entre seus pares. Aqui, é praticamente impossível não recordar de Kuhn (1977) e o desenvolvimento do conceito de comunidade científica. Nesta perspectiva, de uma maneira bastante objetiva, a ciência é uma atividade coletiva e depende do reconhecimento dos pares para provar sua legitimidade.

Quando se fala da Comunicação, no entanto, a rigidez dos métodos oriundos de outras áreas, especialmente das ciências chamadas duras, tem levado a cenários de verdadeira prisão metodológica. Historicamente, tal herança está relacionada à busca incessante por experimentos que pudessem ser reproduzidos em laboratório sempre com a obtenção do mesmo resultado. 
[...] ainda hoje, o senso comum, a imprensa e até mesmo as agências de fomento à pesquisa não sabem muito bem o que fazer com as chamadas "ciências humanas", a Literatura e as Artes, impondo-lhes critérios exógenos e injustificados. Por sua vez, a investigação sobre a comunicação - situada nesse limbo epistemológico que são as chamadas "ciências sociais aplicadas" - vive, desde seu início, um dilema esquizofrênico entre análise objetiva e a interpretação pragmática orientada (VALVERDE, 2010, p. 58).

As tentativas de um encaixe forçado levaram a um empobrecimento dos estudos em Comunicação. Muitos estudos de recepção, por exemplo, ainda insistem em desconsiderar o Outro em detrimento de um receptor passivo quando, em verdade, já se sabe, há muito, que o receptor nunca foi passivo. A própria concepção de passividade sofreu transformações ao longo dos anos. Ainda é possível encontrar estudos que buscam "prever" comportamentos por meio de estímulos quando hoje já se sabe que o homem é um Ser muito complexo, de modo que o que o estimula hoje pode não exercer o mesmo fascínio amanhã (SANTOS, 2017). Os critérios duros de pesquisa (principalmente no que se refere ao método) praticamente soterraram aquilo que a Comunicação tinha (e tem) de mais particular (o sentir, a percepção) em nome de um pseudocientificismo.

Bachelard (2006) apresenta um outro ponto de vista no que se refere ao conhecimento científico que parece libertar a Comunicação das amarras das ciências duras. Na discussão sobre o método, Bachelard (2006, p. 136) afirma que o "[...] espírito científico vive na estranha esperança de que o próprio método venha a fracassar totalmente. Porque um fracasso é facto novo, uma ideia nova." A reprodução incessante do mesmo conduz a uma clareza forçada que impede a visualização do que de fato é o novo, o interessante, o surpreendente. Muitas vezes a pesquisa científica exibe algo que as lentes metodológicas não permitem dar relevo. 0 próprio Goethe chegou a afirmar, durante um Congresso de Filosofia, que "Quem perseverar na sua pesquisa é levado, mais tarde ou mais cedo, a mudar de método." (BACHELARD, 2006, p. 136) A Nova Teoria da Comunicação (NTC) surge como algo radicalmente novo, principalmente no que se refere aos procedimentos de investigação ensejados por ela que negam, veementemente, a aplicação de um método comunicacional.

No escopo da NTC, comunicar não deve se confundir com sinalizar ou informar. Tudo o que existe (pedras, seres humanos, animais etc.) emite sinais, ou seja, recebe-se e emite-se sinais cotidianamente, ainda que não se queira. Alguns sinais podem ocorrer de forma deliberada enquanto outros podem se dar de forma não intencional. Entretanto, como bem destaca Marcondes Filho (2013), a emissão de um sinal não pressupõe, 
necessariamente, a recepção. Uma ação não se liga à outra segundo uma relação de causa e efeito. Cabe a cada um decidir a quais sinais dará atenção. É importante frisar que muitos sinais captam a atenção das pessoas à revelia da vontade delas. É o caso, por exemplo, de um anúncio publicitário que chama a atenção mesmo que não se esteja inicialmente interessado nele. Quando as pessoas percebem, já leram (ouviram, assistiram) o anúncio porque foram atraídas pelas luzes, pelas sensações despertadas, pela chamada textual etc. Também as falas podem ser meros sinais. Prova maior disso é o fato de que todos os dias as pessoas ouvem muitas coisas, mas pouco ou nenhuma importância dão a tudo que ouvem. Quando ocorre o interesse por algo que está sendo dito, exibido, ouvido, então esse sinal se converte em informação, cujo objetivo maior é possibilitar ao ser mais e melhores condições de se adaptar, de agir e de estar no mundo. Trata-se de uma ação deliberada que implica uma escolha, ou seja, cada um vai em busca das informações de que necessita e as incorpora ao seu repertório numa ação de seleção consciente (MARCONDES FILHO, 2011, 2013).

A Comunicação, por seu turno, pressupõe mudança qualitativa de um estado para outro. Isso significa que algo precisa mudar no ser para que se possa afirmar que ocorreu a comunicação. Comunicar é um fenômeno que, a despeito do que apregoa o senso comum, não acontece com tanta frequência, e tampouco pode ser reproduzido em laboratório. Por resgatar a importância do Outro (praticamente negligenciado nas teorias tradicionais e considerado mero receptor), a NTC parte do ponto de vista de criar sentido, de gerar mudança, ruptura. 0 único ser que é capaz de perceber isso é aquele que vivenciou o fenômeno comunicacional. Comunicação, por essa óptica, é algo muito maior, livre de materialidade. Ela se estabelece, entre outros aspectos, na relação com o outro, no princípio da alteridade, e é por essa razão que o Outro recebe especial atenção por parte de Ciro Marcondes Filho (2011), o pai da NTC. Também Buber (2001) faz uma importante reflexão, resgatada por Marcondes Filho (2011), a respeito do tu e do isso. A relação eu-tu é distinta da relação eu-isso. Enquanto a primeira pressupõe o encontro essencial do homem numa atitude de reciprocidade (posto que reconheço o tu), a segunda é calcada na atitude objetivante (o isso deve servir para ser investigado, transformado). Aqui não se fala necessariamente de pessoas, posto que o isso pode se transformar em tu, a depender da atitude que o ser tem diante dos fatos, das pessoas (MARCONDES FILHO, 2011).

A postura diz muito sobre o tipo de relação que se estabelece, posto que tratar uma pessoa como objeto de estudo é vê-la como "isso" (MARCONDES FILHO, 2011). Transformar o isso em tu pressupõe uma nova atitude, um novo comportamento, em que o eu se torna 
permeável ao outro (tu), pois, como destaca Buber (2001, p. 56) “[...] a alteridade essencial se instaura somente na relação EU-TU; no relacionamento EU-ISSO o outro não é encontrado como outro em sua alteridade." (BUBER, 2001, p. 56). Ao basear-se na óptica de Lévinas (2005), Marcondes Filho (2011) defende que o Outro, no fenômeno comunicacional, é tal como é em Lévinas: impenetrável, insondável, aquele que está fora de mim. Não necessariamente está-se falando de uma pessoa, mas sim daquilo que o ser não é e, exatamente por isso, é aquilo que rompe o ego e possibilita ver além de si mesmo. A comunicação pressupõe, desta forma, o reconhecimento do Outro, mas não apenas isso. É preciso romper a barreira que há em mim para acolher, hospedar o Outro que me choca (por ser tão diferente de mim) e que pode até mesmo me agredir dada a sua estranheza. É preciso abrir-se. Essa abertura, no entanto, não acontece sempre numa situação dialógica, como queria Buber (2001); ela pode ocorrer pelo atrito, pelo radicalmente oposto, pela formação de ranhuras e fissuras na alma.

\section{Comunicação como ruptura}

Nem sempre a opção por acolher o Outro ocorre sem atrito. Mas é justamente a formação dessas ranhuras que vai possibilitar uma guinada, uma transição, um salto qualitativo. Marcondes Filho (2011) defende que a comunicação genuína deve romper algo internamente dentro do ser; aquilo que era, de repente já não é mais. Essa transformação acontece de "um só golpe", nas palavras do autor. Não é um fenômeno de racionalização, mas de intuição, de apreensão sensível. A linguagem, por sua vez, também não consegue dar conta de todo o fenômeno porque é limitada; assim sendo, a comunicação está fora de seu domínio. Não há como expressar, por exemplo, a dor para alguém. A palavra dor pode até ser compreendida pelo receptor, mas ele nunca será capaz de compreender com exatidão a dimensão da dor que alguém sente. E na possibilidade (ainda que utópica) de compreendêla, jamais saberia exatamente como essa dor impacta o ser que a sente. 0 interior, os recônditos de um ser, pertence a ele e somente a ele.

Livre de materialidade, o sentido da comunicação se estabelece num momento específico e sempre é mutável porque o ser está em constante transformação. Marcondes Filho (2016) explica que se trata de algo irrepetível, que só ocorre uma vez, num instante oportuno, sob o cruzamento de forças e vetores inexplicáveis. Mesmo que as condições ideais sejam as mesmas, o sentido gerado será completamente distinto porque depende do 
Outro que foi, é, e sempre será um mistério. Seguindo esse raciocínio e buscando permitir que a Comunicação - como ciência - alcance a maioridade, como diz Marcondes Filho (2011, 2008), é necessário entender que o específico da comunicação só é possível mediante a realização de um "acontecimento" capaz de realizar um corte, uma ruptura que, paradoxalmente, introduza vida na relação ao encaminhar uma mudança radical no que éramos e no que nos tornamos após essa "quebra". Os acontecimentos são também únicos e implicam situações singulares que ensejam verdadeiros movimentos de liberdade.

Quando a comunicação ocorre tem-se, portanto, um Acontecimento comunicacional, o ponto nodal da comunicação, a pulsação, linhas propagadoras de luz. Aqui, estamos tratando do sentido que se forma junto com o Acontecimento comunicacional. Este, por seu turno, é único e nenhum ser humano pode transferi-lo, pois apenas ele - sujeito que experiencia a comunicação, a vivência com a alteridade - é capaz de saber a amplitude da provocação que o acontecimento lhe causou. Uma vez iniciado, não há ponto de retorno, ou seja, uma vez experienciado o Acontecimento comunicacional, não há mais como voltar ao que era antes. É importante destacar que o Acontecimento comunicacional não ocorre num espaço específico, numa determinação geográfica, ou ainda, "sob condições ideais de temperatura e pressão". Ele é um fenômeno único, irrepetível. Em virtude de tais aspectos, Marcondes Filho $(2011,2008,2004)$ defende que a comunicação está no entre e no durante (de onde o Princípio da Razão Durante). Conceitualmente, a razão durante corresponde ao "[...] princípio segundo o qual o acontecimento comunicacional tem sua existência, seu efeito e sua força na fração de tempo exata de sua duração." (MARCONDES FILHO, 2011, p. 91). É importante deixar claro de que duração está-se falando. Como é produto de uma série de forças, vetores, energias, vivências e situações, o Acontecimento comunicacional tem uma duração específica não determinável. Não há sequer como localizar a mudança, a guinada qualitativa, justamente porque a comunicação se dá, conforme já dito, no Entre e no Durante. Isso significa dizer que o acontecimento se dá no espaço entre os interlocutores e durante um período muito especial. Não se trata de algo domesticável e que possa ser parado, congelado para ser pesquisado, desmembrado.

A comunicação é inesperada, surpreendente, selvagem e indomável. Não há como ditar regras para que ela ocorra. Para apreender o fenômeno, é preciso que o pesquisador se instale na mudança enquanto ela ocorre. Merleau-Ponty (1994) fala da necessidade de sentir, de dissolver-se na carne do mundo. Para o filósofo, o sentir está relacionado à instalação do ser no mundo porque, em estando nesse local de vivência, é impossível ao ser 
agir como se não estivesse em tal situação. 0 acompanhamento do fenômeno pressupõe, primeiro, o seu reconhecimento. Reconhecendo-o, é preciso que o pesquisador entenda que tudo se move porque o mundo não cessa seu movimento simplesmente porque alguém iniciou uma pesquisa científica. De acordo com Bergson (2006), o movimento não pode ser decomposto em estados sucessivos ou ainda em uma série de posições concatenadas, uma seguida da outra.

O movimento é um todo e não deve se confundir com a trajetória. As tentativas ainda que frustradas - de paralisar o mundo ou mesmo de tentar controlá-lo, faz com que diversos pesquisadores da área de comunicação lancem mão de artifícios como controle de variáveis. Nos projetos de pesquisa enviados para as agências de fomento, isso aparece como variáveis dependentes e variáveis independentes. Em verdade, é impossível exercer esse tipo de controle em ciências humanas e ciências sociais aplicadas. Essas áreas, pelo menos na maior parte das vezes, investigam o "vivo" e não o "morto" que será aberto e investigado sob diversos aspectos. 0 "vivo" da comunicação corresponde a um ser que é, em verdade, um "[...] evento-enquanto-ocorrência, um acontecimento casual enquanto atrito, pela fricção, pelo impacto, pelo encontro do bisturi com a carne, do fogo com a madeira, da palavra com o ser." (MARCONDES FILHO, 2011, p. 95, grifo do autor). A relação que se estabelece nesse espaço entre uma coisa e o ser é tão umbilical que não há mais como distinguir (e nem se busca isso) quem é o tocado e quem é o tocante, o vidente e o visível. Estabelece-se uma amálgama que dispensa reflexões e problematizações racionalizadas. Tudo aquilo que existe como conhecimento em nossa consciência passou, antes, pela nossa percepção (MERLEAU-PONTY, 1994). A sensação não obedece às normas, às regras do intelecto, os atos inconscientes predominam sobre os conscientes, de modo que não se refletem sobre tudo a todo o momento. Percebe-se, antes de pensar. Sente-se; o ser abre-se para o mundo.

\section{A pesquisa sob uma nova perspectiva}

Investigar o "vivo" pressupõe abrir-se para ele, instalar-se nele, banhar-se em seu contexto para efetivamente sentir a ocorrência da comunicação e mover-se com ela e com todos que a ela se relacionam. Dadas as especificidades do objeto de estudo (que, na pesquisa fundada na NTC é um ser com quem o pesquisador estabelece uma relação do tipo eu-tu e não eu-isso), fica claro que a concepção de método tradicional não oferece respaldo 
suficiente para captar as nuances das transformações ocorridas no Acontecimento comunicacional. Ele é a base e, por sua vez, pode ser observado, dadas as suas características de novidade, efemeridade, movimento e imprevisibilidade. Tais características ficam mais evidentes quando são expostas e aplicadas ao foco da pesquisa: “[...] o objeto não é conhecido, nem conceituado; não permanece por muito tempo; não está parado, estacionado ou 'congelado' e não avisa quando irá acontecer novamente." (MARCONDES FILHO, 2011, p. 192).

Os métodos tradicionais de pesquisa não conseguem corresponder à fruição do Acontecimento, mesmo porque, não raro, tais métodos buscam entender, compreender, analisar, dar sentido a ele. Diferentemente da pesquisa clássica ou tradicional, a pesquisa que assume a comunicação como um Acontecimento pressupõe a necessidade de "reescrever" os caminhos e de revisitar os temas em função do novo contexto, mas, sobretudo, em função do momento. Assim, a ideia de métodos preestabelecidos e constantemente aplicados, facilmente reproduzíveis, não cabe na perspectiva da Nova Teoria da Comunicação. 0 "vivo" está justamente na ausência de um método fixo, definitivo, fechado, asséptico. Ao pesquisador cabe descobrir formas de olhar e estudar o objeto que, nesta perspectiva, não será esgotado ou dissecado. 0 pesquisador não precisa (e não deve) buscar conhecer todas as nuances do objeto. A compreensão do objeto reside em um momento, em um contexto. Ao invés de seguir um caminho pré-determinado (método), o pesquisador embrenha-se no acontecimento, por meio de seus poros. Daí a razão porque a pesquisa que assume a NTC não pressupõe um método específico e sim o metáporo (caminho pelos poros). Quantas vezes se olhe para o mesmo objeto, tantas vezes será preciso reconstruir e redescobrir formas distintas de observá-lo. A mente precisa estar aberta para os movimentos constantes do mundo. Tais movimentos são únicos e irreproduzíveis, passíveis de percepções que também serão únicas. Ao trabalhar a lógica da pesquisa científica, Popper (1974, p. 61-62) afirma que as teorias são redes “[...] lançadas para capturar aquilo que denominamos 'o mundo': para racionalizá-lo, explicá-lo, dominá-lo [...]” e, de acordo com tal princípio, quanto mais estreita a rede, melhor. 0 método serviria para captar aquilo que os sentidos falseiam, ou seja, aquilo que é captado pelo sentido deve ser constantemente submetido à prova.

De forma diametralmente oposta e assumindo a epistemologia metapórica, a NTC está assentada na perspectiva de que o pesquisador se torna a rede (grifo meu). Ele deixa de ser o sujeito que lança a rede e apenas observa para se tornar a própria rede. Embora exista 
proximidade com a pesquisa participante e também com a pesquisa-ação, é importante destacar que o pesquisador que assume a Nova Teoria sente o que se passa ao seu redor e se coloca na cena do Acontecimento. Existe, na Nova Teoria, a valorização do sentir e do percepcionado. De forma semelhante, também existe proximidade entre a pesquisa metapórica e a pesquisa cartográfica. 0 ponto de convergência está no fato de que ambas trabalham com a premissa de que pesquisador e pesquisado compartilham a mesma realidade (o comum). Por outro lado, o ponto de distanciamento está no fato de que, no segundo tipo de pesquisa citado, "[...] o pesquisador sai da posição de quem - em um ponto de vista de terceira pessoa - julga a realidade do fenômeno estudado, para aquela posição ou atitude (o ethos da pesquisa) - de quem se interessa e cuida." (KASTRUP; PASSOS, 2013, p. 272, grifo do autor). Observa-se aqui, ainda que de forma sutil, que o pesquisador ainda assume o papel do cuidador.

A pesquisa metapórica, por sua vez, abre espaço para que o pesquisador seja, em muitos casos, o cuidado e não o cuidador. Isso ocorre porque o metáporo pressupõe olhar para si mesmo. Ele habilita o pesquisador a ser, antes de tudo, um ser humano que sente. Nesse sentido, mais que a mera recepção de conteúdos por meio dos órgãos dos sentidos visão típica do empirismo - interessa ao pesquisador do metáporo destacar a percepção no sentido defendido por Merleau-Ponty (1994). Para ele, a percepção não é uma representação fria apreendida pelos órgãos dos sentidos. Igualmente, a percepção em Merleau-Ponty (1994) é um acontecimento da existência com características corpóreas. A percepção está calcada na experiência de um Sujeito que olha para o objeto e sente, torna-se parte dele. 0 corpo, por sua vez, realiza a percepção no movimento. A imobilidade o deixa confuso, atrofiado, preso (MERLEAU-PONTY, 1994). Viver é habitar o mundo e mover-se nele. Ao direcionarmos nosso olhar para o objeto, colocamo-nos na posição de quem deseja habitá-lo, de forma que "[...] as sensações aparecem associadas a movimentos e cada objeto convida à realização de um gesto, não havendo, pois, representação, mas criação, novas possibilidades de interpretação." (NÓBREGA, 2008, p. 142). A obra de arte, neste sentido, é o local que possibilita frestas para experiências perceptivas mais intensas. 0 pesquisador do metáporo precisa, também, despir-se de um pensamento preestabelecido e estar aberto para observar os movimentos do novo, assumindo um papel de espectador do mundo (DANTAS, 2012). Esse espectador, em sendo parte do mundo, também é o mundo e atravessado por linhas, vetores e sensações únicas em situações únicas. O conhecer seus 
parâmetros. A relação constrói o objeto e não o contrário (como apregoam as teorias clássicas).

Se, por um lado, a acepção do metáporo possibilita pesquisas antes impossíveis sem essa visão, por outro, também impõe desafios a um objeto que não é controlado. É cômodo (e até mais seguro) para o pesquisador que ele se debruce sobre um objeto estático. 0 metáporo impõe a necessidade de acompanhar o movimento, o que nem sempre é confortável para pesquisadores que, por mais que se esforcem, ainda carregam a herança de uma ciência calcada em métodos rígidos. Trata-se, portanto, de uma rebeldia acadêmica necessária: libertar-se das amarras e perceber-se no mundo. 0 pesquisador que não se percebe não será capaz de desenvolver uma pesquisa metapórica porque ela depende, necessariamente, da sensibilidade dele. 0 pesquisador não visa apreender, capturar ou dissecar algo. Ele busca vivenciar e sentir o fenômeno. Um pesquisador "morto" tampouco será capaz de sentir algo vivo, porque nele não haverá mais fôlego intelectual, vontade, desejo. Há aqui também um ponto importante: o pesquisador do metáporo precisa despir-se da autoridade, tão cara a pesquisadores conservadores.

O metáporo opera pelos poros, um espaço, uma passagem que me permite visualizar o Acontecimento comunicacional que, por sua vez, deixa-se ver. 0 pesquisador do metáporo não conta, portanto, com um método específico, o que não significa ausência de cientificidade. Ainda que não partilhe exatamente do ponto de vista defendido por Marcondes Filho (2011), Valverde (2010, p. 59) entende que: “[...] é preciso criticar e rejeitar a rigidez metodológica sem cair na apologia do relativismo, respeitando a especificidade de cada objeto de investigação, mas assumindo as responsabilidades que todo trabalho conceitual exige." E é justamente assumindo tais responsabilidades que o pesquisador do metáporo conta com formas de operacionalização que se traduzem, em essência, em linhas mestras que norteiam sua postura mediante o objeto em questão (passos metapóricos). Sua busca não é o significado, mas sim o sentido, o sensível, que só é despertado diante de uma comunicação de ruptura.

O Acontecimento, condição essencial para que isso ocorra, não tem um sentido, ele é o sentido, isto é, ao estudá-lo, estamos colocando em cena o acontecimento como um todo, no momento em que ocorre, independentemente de sua duração. É requerido do pesquisador do metáporo uma grande habilidade para narrar e registrar os acontecimentos. A linguagem, nesse caso, pode ser um entrave, uma vez que nem tudo que se vivencia pode ser expresso em palavras ou textos, mas é preciso buscar formas para transmitir o clima, a 
pulsação, a vibração experimentados. É preciso estar aberto para a apreensão instantânea do fenômeno. Essa necessidade repõe a importância da intuição intelectual, ou seja, “[...] fatos que antecedem e que sucedem a intuição sensível." (MARCONDES FILHO, 2011, p. 254). A intuição intelectual pode ocorrer antes ou após a intuição sensível, de acordo com objeto em questão, o que vai depender da temporalidade metapórica definida por Marcondes Filho (2011, p. 254) como "[...] uma temporalidade estendida marcada pelos picos de êxtase." Esses picos correspondem à intuição sensível e ao momento da virada, da ocorrência do fenômeno que justifica a afirmação de ocorrência da comunicação genuína, capaz de possibilitar a ruptura e a marca de algo que atravessa o Sujeito, que rompe, que violenta, que choca. Essa virada, a transformação que choca e violenta, pode acontecer nos primeiros instantes da relação, como no caso de uma emoção forte ou mesmo no cinema, e os efeitos serão sentidos em momentos posteriores. Nesse caso, a intuição intelectual se processa no depois, de modo que algo permanece ressoando no sujeito, transformando o após a exibição de uma obra cinematográfica, por exemplo. Mas, em situações educacionais, o sentido é diferente: "[...] as informações são jogadas formando a intuição intelectual, até que num momento ocorre a intuição sensível, que cria o sentido, portanto, o pico intuitivo ocorre no final [...]" (DANTAS, 2012, p. 12).

Ao pesquisador que assume esta nova vertente de teoria, cabe observar o fenômeno comunicacional, senti-lo e relatá-lo. Parte-se, aqui, do ponto de vista de que uma nova teoria sempre abre novos horizontes ou ainda novas formas de enxergar o mesmo horizonte.

\section{Considerações finais ou como fazer...}

Como fazer isso? Após todo este caminho, só há uma resposta: vivendo, lançando-se no mar dos Acontecimentos sem medo de se perder. Aliás, a resposta só virá junto com a sensação de estar perdido. A luz só se faz presente quando há escuridão. Não há como ser diferente. Qualquer elemento fora disso será repetição. Finalmente, talvez alguém questione: qual a importância de uma pesquisa desta natureza? Resposta: além de oferecer estudo acerca da valorização da pesquisa que se produz na América Latina, este tipo de pesquisa liberta o Ser da visão, há muito viciante, de que só existe uma forma "correta" de fazer ciência (aquela apregoada pelos críticos e especialistas). Este tipo de investigação tem como fundo a democratização do Saber sem culpa por não ver aquilo que todos achavam que deveria ser visto. É a derrubada do (bom) gosto ou da metodologia dura. Em Crítica muda e cega (conto constituinte da obra Mitologias), Roland Barthes (2001, p. 28) afirma: 
“[...] a cultura é permitida com a condição de proclamar periodicamente a vaidade dos seus fins e os limites do seu poder." Não importa o que dizem os críticos ou manuais; importa apenas aquilo que toca, aquilo que faz mover. E isso não é errado! Ademais, o movimento de libertação não cessa aqui. Estudar a Nova Teoria da Comunicação pressupõe a valorização da Ciência que é feita no Brasil. Destaca-se, por outro lado, que em nenhum momento propõe-se que se esqueça todo o resto. Muito pelo contrário: é preciso agregar. Adotar a Nova Teoria da Comunicação não significa esquecer tudo o que já foi construído até aqui, mas vislumbrar novas possibilidades.

Este é, talvez, o maior exercício de liberdade proposto e executado aqui: a desvinculação do colonialismo acadêmico - aquele que aprisiona nos tradicionalismos e que não responde às ansiedades e necessidades, mas que se consagrou em virtude de uma autoridade arcaica há muito instituída nas Universidades. Diante disso, a rebeldia é necessária para se encontrar no meio disso tudo. 0 respeito a uma nova visão é também uma luta. Existem espaços claramente definidos e delimitados, mas é preciso ter esperanças. Ter esperanças de que, um dia, diferente de Núnez, do conto de Herbert George Wells, denominado Em terra de $\mathrm{cego}^{2}$, os adeptos de novas formas de ver a Ciência não precisarão fugir para manterem os olhos e a visão alternativa da realidade.

\section{Referências}

AGAMBEN, Giorgio. Infância e história: destruição da experiência e origem da história. Belo Horizonte: Ed. da UFMG, 2005.

BACHELARD, Gaston. A epistemologia. Lisboa: Edições 70, 2006.

BACHELARD, Gaston. 0 novo espírito científico: contribuição para uma psicanálise do conhecimento. Rio de Janeiro: Contraponto, 1996.

BARTHES, Roland. Mitologias. Rio de Janeiro: Bertrand Brasil, 2001.

BERGER, Charles R. Por que existem tão poucas teorias da comunicação? In: MARTINO, Luiz (Org.). Teorias da comunicação: muitas ou poucas? Cotia: Ateliê Editorial, 2007.

BERGSON, Henri. 0 pensamento e o movente: ensaios e conferências. São Paulo: Martins Fontes, 2006.

\footnotetext{
2 Escrito em 1904, por Herbert George Wells, The country of the blinds (traduzido como: Em terra de cego), é um conto que retrata a chegada de um homem vidente a um local habitado unicamente por pessoas cegas há várias gerações. Sua habilidade (a visão) logo a passa a ser encarada pelos demais como aquilo que dificulta sua vivência em grupo, resultando, ao final do conto, na fuga do vidente para que pudesse manter sua faculdade de ver. Este conto contradiz o dito popular de que "Em terra de cego, quem tem olho é rei". Em verdade, Wells mostra o quanto temos dificuldade de aceitar o diferente e conviver com ele. A intolerância chega ao limite máximo quando, no conto, propõe-se que o personagem Núnez abra mão de sua visão.
} 
BUBER, Martin. Eu e tu. 5. ed. São Paulo: Centauro, 2001.

DANTAS, Elenildes. Apresentando o metáporo, o meio de estudar a comunicação como acontecimento. In: CONGRESSO DA LUSOCOM, 10., 2012, Lisboa. Anais... Lisboa: ISCSP, 2012.

FREIRE, Paulo. Extensão ou comunicação? 7. ed. Rio de Janeiro: Paz e Terra, 1983.

KASTRUP, Virgínia; PASSOS, Eduardo. Cartografar é traçar um plano comum. Fractal: Revista de Psicologia, Rio de Janeiro, v. 25, n. 2, p. 263-280, ago. 2013.

KUHN, Thomas. A tensão essencial. Lisboa: Edições 70, 1977.

LEVINAS, Emmanuel. Entre nós: ensaio sobre alteridade. 2. ed. Petrópolis: Vozes, 2005.

LITTLEJOHN, Stephen W. Fundamentos teóricos da comunicação humana. Rio de Janeiro: Guanabara, 1978.

MARCONDES FILHO, Ciro. 0 escavador de silêncios: formas de construir e de desconstruir sentidos na comunicação. Nova teoria da comunicação II. São Paulo: Paulus, 2004.

MARCONDES FILHO, Ciro. o princípio da razão durante: o conceito de comunicação e a epistemologia metapórica. São Paulo: Paulus, 2011.

MARCONDES FILHO, Ciro. 0 rosto e a máquina: o fenômeno da comunicação visto pelos ângulos humano, medial e tecnológico. São Paulo: Paulus, 2013.

MARCONDES FILHO, Ciro. Para entender a comunicação: contatos antecipados com a Nova Teoria. São Paulo: Paulus, 2008.

MARCONDES FILHO, Ciro. Sobre o tempo de incubação na vivência comunicacional. In: ENCONTRO ANUAL DA COMPÓS, 25., 2016, Goiânia. Anais... Goiânia: Compós, 2016.

MARTINO, Luís Mauro Sá. Teoria da comunicação: ideias, conceitos e métodos. Petrópolis: Vozes, 2009.

MASSONI, Neusa Teresinha. Ilya Prigogine: uma contribuição à filosofia da ciência. Revista Brasileira de Ensino de Física. São Paulo, v. 30, n. 2, p. 2308.1-2308.8, 2008.

MERLEAU-PONTY, Maurice. Fenomenologia da percepção. São Paulo: Martins Fontes, 1994.

MORAES, Maria Candida. 0 paradigma educacional emergente. Campinas: Papirus, 2000.

NOBREGA, Terezinha Petrucia da. Corpo, percepção e conhecimento em Merleau-Ponty. Estudos de Psicologia, Natal, v. 13, n. 2, p. 141-148, maio/ago. 2008. Disponível em: <http://ref.scielo.org/h9k3xh>. Acesso em: 1 maio 2017. 
POPPER, Karl. Lógica da pesquisa científica. São Paulo: Cultrix, 1974.

ROSA, Carlos Augusto de Proença. História da ciência: o pensamento científico e a ciência no século XIX. 2. ed. Brasília, DF: FUNAG, 2012.

SANTOS, Vanessa Matos dos. Repensar os audiovisuais em uma proposta metapórica: em busca do sensível. 2017. Tese (Doutorado em Meios e Processos Audiovisuais) Universidade de São Paulo, São Paulo, 2017. Disponível em: <http://www.teses.usp.br/teses/disponiveis/27/27161/tde-07072017-155921/ptbr.php>. Acesso em: 31 out. 2017.

SODRÉ, Muniz. A ciência do comum: notas para o método comunicacional. Petrópolis: Vozes, 2014.

VALVERDE, Monclar. Comunicação e experiência estética. In: LEAL, Bruno; GUIMARÃES, César; MENDONÇA, Carlos (Org.). Entre o sensível e o comunicacional. Belo Horizonte: Autêntica, 2010.

\title{
Communication as rupture: nuances of a new Brazilian contribution
}

\begin{abstract}
The conception of discursive territories engenders political places and, although in an indirect way, presupposes a kind of cognitive and epistemic colonization. Communication studies in Brazil and Latin America are still massively marked by theoretical contributions and concepts that have been forged taking into account contexts other than those of Ibero-America. Aiming to present an important progress achieved in Brazil, this article presents the New Theory of Communication (NTC) and the concept of communication as rupture and consequent opening to the Other. Given this opening, the NTC does not work with methodological rigidity but, rather, with the rigor in narrating events through the metáporo. The aim is to demonstrate, above all, that researching with metaphorical procedures leads to a new relationship between researcher and object of research that allows us to glimpse new perspectives in a field as complex as that of Communication.
\end{abstract}

\section{Keywords}

New Theory of Communication. Rupture. Epistemology. Metáporo. 